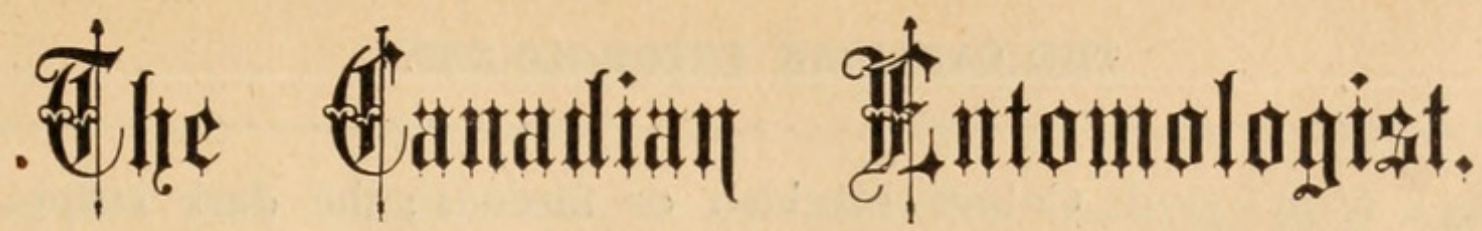

VoL. XXXVI.

LONDON, JULY, I 904 .

No. 7

\section{THE CRICKFTS OF ONTARIO.}

BY E. M. WALKER, B. A., M. B., TORONTO.

(Continued from page I44.)

Subfamily GryLLINÆ.

This subfamily includes the common field and ground crickets, and is represented in Ontario by two genera, Nemobius and Gryllus. These may be separated as follows :

a. Small species; last joint of maxillary palpi twice as long as the one preceding; hind tibiæ furnished with long movable spines; first joint of hind tarsi unarmed above, or with one row of small

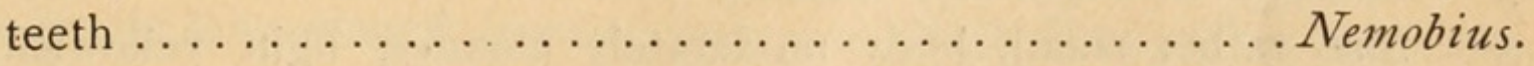

aa. Medium-sized or large species; last joint of maxillary palpi but little, - if any, longer than the one preceding; hind tibiæ armed with short immovable spines: first joint of hind tarsi sulcate above, with a row of teeth on each side................. Gryllus.

Genus Nemobius.

This genus is best known by the common little striped ground cricket ( $N$. fasciatus), which abounds in our fields and roadsides in late summer and autumn. Our other species are all much more local and less numerous in individuals, and are not likely to be taken by the collector unless he is specially looking for them.

Key to Ontario species of Nemobius.

a. Ovipositor as long as or barely shorter than the hind femora, straight or nearly so.

b. Ovipositor distinctly longer than hind femora, black of body arranged in lengthwise bars.

c. Ovipositor a fourth longer than hind femora, colbur light grayish, with distinct black markings; size medium or rather small .............. $N$. griseus, n. sp.

cc. Ovipositor not more than about an eighth longer than hind femora, size large. 
d. Colour blackish or fuscous; the dark stripes on occiput always visible, though sometimes indistinct in very dark specimens ...2. N. fasciatus. dd. Colour light reddish-brown or grayish; without dark stripes on occiput ............. $N$. canus.

bb. Ovipositor no longer than hind femora; black of body scattered in blotches and dashes .............. N. maculatus.

aa. Ovipositor distinctly shorter than hind femora, usually more or less arcuate.

e. Small species ; tegmina of male covering about three-fourths of the abdomen, last two joints of maxillary palpi in female dark brown ................... palustris.

ee. Medium-sized species; tegmina of males reaching tip of abdomen, last two joints of maxillary palpi in female light brown $\ldots \ldots \ldots \ldots \ldots \ldots \ldots \ldots$. $N$. angusticollis, n. sp.

\section{Nemobius griseus, new species.}

Size rather small, body moderately slender, light yellowish gray, covered with fine short closely-appressed gray hairs. Head about as wide as the pronotum, rather large, full and rounded; below the antennæ deep shining piceous, elsewhere yellowish gray, the occiput with three distinct dark gray longitudinal bands. Eyes of average size, about as prominent as in $N$. fasciatus, but rounder than in that species. Maxillary palpi dark reddish-brown, the third joint and the apex and base, respectively, of the second and fourth lighter. A dark piceous band starts behind the eye and covers the lateral lobe of the pronotum, except the extreme lower margin, which is light yellowish. Pronotum nearly three-fourths as long as broad, widening slightly posteriorly, dorsum pale yellowish-gray, sparsely covered with black bristles. Tegmina of of usually covering about three-fourths of the abdomen, and fitting closely to the latter, pale yellowish, with the upper half or more of the lateral field shining black, a black streak along the dorsal field near the inner margin, and usually two or three smaller black patches near the base. Tegmina of $q$ usually covering about one-half the abdomen, the hind margin less convex than in fasciatus, pale testaceous, a shining black stripe along the upper third of the lateral field, a black streak on the dorsal field between its puter and middle thirds, and a few short streaks and spots on the inner two-thirds. Wings absent or fully developed, and extending beyond the tips of the hind femora by more than one-half their length.

Abdomen in of glossy black 
on dorsal and lateral surfaces, grayish-yellow beneath; in $f$ with the dorsal surfaces of the first three segments shining black, elsewhere yellowish-gray, with a row of dark spots along the dorsum. Hind femora dark sooty brown above, with a few small light spots along dorsal surface, the dark colour extending down irregularly over about half or more of the inner and outer surfaces, where it is more or less broken into blotches; elsewhere pale testaceous, lighter internally. Legs dark sooty brown, variegated with pale testaceous. Ovipositor about as long as the body, and about one-fourth longer than the hind femora, nearly straight, stout, the apical blades tapering evenly to a fine point, the teeth sharp, prominent, and nearly equidistant.

Length of budy, \& $7 \mathrm{~mm}$., \& $8 \mathrm{~mm}$.; pronotum, of $1.5 \mathrm{~mm}$, \& 1.75 mm.; tegmen, कै $3.5 \mathrm{~mm}$., क $2.9 \mathrm{~mm}$.; hind femur, of $5 \mathrm{~mm}$., क $6 \mathrm{~mm}$.; ovipositor; $7.7 \mathrm{~mm}$.

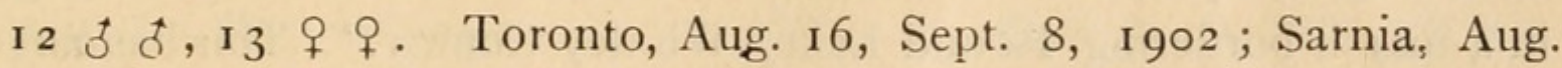
I6. I90 I ; De Grassi Pt., Lake Simcoe, Aug. 3, I903; Sept. I5, I901. I have a single long-winged female, taken at High Park, Toronto, Aug. I6, I902.

This is a well-marked species, easily distinguished from $N$. fasciatus by its much smaller size, grayish coloration, more distinct dark markings and longer ovipositor. It has the longest ovipositor of any of our species.

It occurs only on sandy soil, where the vegetation is somewhat scanty. I have never taken it in large numbers, but in High Park, where all my Toronto specimens were taken, it is by no means scarce when looked for in the proper kind of locality. Its pale colours renders it very inconspicuous against the sand.

The chirp of the male is a feeble, continuous trill, more high-pitched than that of fasciatus or angusticollis, and much shorter than either.

4. Nemobius fasciatus, De Geer. The Striped Ground Cricket.

Gryllus fasciatus, De G., Mem. pour serv. à l'hist. des ins., III.,

\section{I $773,55^{2}$.}

Nemobius fasciatus, Scudd., Mat. Mon. N. A. Orth., VII., IS62, 430. Acheta vittata, Harr., Ins. Inj. Veg., I862, I 52.

Nemobius vittatus, Scudd., Mat. Mon. N. A. Orth., VII., I862, 430. Nemobius fasciatus vittatus, Beut., Bull. Amer. Mus. Nat. Hist., VI., I 894,267 .

Nemobius exiguus, Scudd., Mat. Mon. N. A. Orth., VII., I 862, 429. 
Length of body, f $9 \mathrm{~mm}$., $q$ io mm.; pronotum, of $\mathrm{r} .5 \mathrm{~mm}$., $q$ $2 \mathrm{~mm}$.; tegmen, of $5.5 \mathrm{~mm}$., $\uparrow, 4 \mathrm{~mm}$; hind femur, of $6.3 \mathrm{~mm}$., $q 7$ $\mathrm{mm}$.; ovipositor, $9 \mathrm{~mm}$.

I have found this cricket in abundance in all parts of Ontario where I have made collections of Orthoptera. In this species the tegmina usually cover about three-quarters of the abdomen in the $\delta$, and about half the abdomen in the $q$, and in such specimens the wings are absent. This is the form that was formerly known as vittatus. Specimens with wings extending far beyond the end of the abdomen are often met with, however, and are most often seen at night, when they are attracted to light. These long-winged individuals are usually, but not always, females. Blatchley says of this species in Indiana: "During hundreds of days spent in field collecting, not a single specimen of the long-winged form was taken until Aug, I, I 902 , when it was found in numbers on the stems of long grass in a marsh bordering Round Lake, Whitley County." This has not been my experience, as I have frequently come across it in the field. On Aug. 26, I 90 I, I found large numbers of this form floating on Lake Huron, about a quarter of a mile from the south shore of the Bruce Peninsula. It was a hot, still day, and many other insects were seen floating in the same manner, notably two other Gryllidæ, the tree cricket, Ecanthus fasciatus, and the long-winged form of Gryllus abbreviatus This species reaches maturity towards the latter part of July, and continues until severe frost, usually in the early part of November.

Specimens from the south-west appear to average larger than those from the north. My largest ones are from Arner, Essex Co., close to the shore of Lake Erie.

Localities: Niagara Falls, Point Pelee, Arner, Chatham, Sarnia, Goderich, Southampton, Bruce Peninsula, Owen Sound, Hamilton, Toronto, Lake Simcoe, Severn River, Lake Muskoka, Algonquin Park, North Bay, Stony Lake (Peterboro' Co.).

1 Mr. Blatchley has called my attention to a small dark Nemobius which he has taken in Northern Indiana, Michigan, and in Ontario across from Buffalo, N. Y. I have also taken this form, and I agree with Mr. Blatchley in considering it to be a small degenerate form of fasciatus.

5. Nemobius canus, Scudd.

N. canus, Scudd, Journ. N. Y. Ent. Soc., IV., ז896, 1०0, 103.

I have a single $q$ Nemobius taken at Arner, Ont., which agrees pretty well with Blatchley's description of canus. The head is light 
reddish-brown, without any trace of the fuscous stripes which are so constant a feature in fasciatus. The general coloration is light reddishbrown, with the dark markings more distinct than in fasciatus. The eyes are more globose than is usual in that species. It may be only an atypical specimen of fasciatus, but it appears to show the chief peculiarities by which canus is known from the latter.

6. Nemobius maculatus, Blatchley.

N. maculatus, Bl., Psyche, IX., I900, 52.

On Aug. 22, 1903, when collecting near Tobermory, on the Bruce Peninsula, I found a small Nemobius in considerable numbers jumping about in a small patch of moss in the spruce woods. I captured 4 s $\delta$ and $3 q q$, and on my return to Toronto sent a pair to Mr. Scudder, who named them $N$. maculatus. They do not agree with Blatchley's description in all respects, and I do not feel satisfied that they really belong to that species. The ovipositor in maculatus is equal to or very slightly shorter than the hind femora, whereas in my specimens it is slightly longer in one and distinctly longer in the other two. The tegmina are shorter than the average in $N$. fasciatus, but are longer than those of typical maculatus, according to the description. They agree with the latter in having fine cross veinlets in the of tegmina. The coloration does not show the spotty pattern of maculatus in any marked degree.

Length of body, of $8 \mathrm{~mm}$., क $8 \mathrm{~mm}$; pronotum, of $1.5 \mathrm{~mm}$., $q$ i.6 $\mathrm{mm}$; tegmen, of $3.5 \mathrm{~mm}$., $q 2.75 \mathrm{~mm}$; hind femur, of $5 \mathrm{~mm}$., +5.3 $\mathrm{mm}$.; ovipositor, $6.5 \mathrm{~mm}$.

7. Nemobius Palustris, Blatchley. The Marsh Ground Cricket.

$N$. palustris, Bl., Psyche, IX., I900, 53.

Length of body, of $5.5 \mathrm{~mm}$., $q 6 \mathrm{~mm}$; pronotum, of $q$ I $\mathrm{mm}$.; tegmen, of $2.7 \mathrm{~mm}$., \& $2 \mathrm{~mm}$; hind femur, of $3.5 \mathrm{~mm}$., क $4 \mathrm{~mm}$; ovipositor, $3 \mathrm{~mm}$.

On the I 8 th of August, I903, I came across this handsome little cricket in a sphagnum swamp on the margin of Ragged Lake, Algonquin Park. The swamp bordered the lake for a few hundred yards about the mouth of a small creek, and was of a very interesting character. It was carpeted throughout with a deep growth of sphagnum moss, in which cranberries (Oxycoccus macrocarpus) were growing in the greatest profusion. Pitcher-plants (Sarracenia purpurea), various Ericaceæ, such as Andromeda polifolia and Chamcedaphne calyculata, were also conspicuous among the plants, the only trees being a few dwarf specimens of black 
spruce and tamarack. For about a hundred yards beyond the margin of the creek the swamp was a true floating bog, and the trees very few and small ; and it was here that the crickets were found. They were present in considerable numbers, but were very difficult to capture, and when alarmed would at once burrow down among the masses of sphagnum. By pressing these masses down under water, it was often possible to bring the crickets to the surface.

Mr. Blatchley, to whom I sent a pair, remarks that the specimens are smaller than typical ones from Indiana. They are much the smallest of the Ontario Nemobii.

My attention was first called to this species by its chirp, which is a continuous and rather feeble trill, very like that of $N$. angusticollis.

8. Nemobius' angusticollis. New species.

N. palustris, Walk., Ann. Rep. Ent. Soc. Ont., I 90 I, 109.

Size medium, body of male very broad. Head small but prominent, dark shining brown, more or less obscurely trifasciate above with darker brown, rather scantily covered with black bristles. Eyes small but prominent, oval. Maxillary palpi light brown, the terminal joint infuscated apically. Pronotum nearly smooth, somewhat shining dark piceous, more or less faintly variegated with lighter brown, sparsely covered with black bristles; slightly narrower at the anterior margin than the head, about equal to it in width at the hind margin; a rather deeply impressed median longitudinal line on the anterior half. Tegmina of $\delta$ reaching tip of abdomen, very broad, the dorsal breadth being much greater than that of the pronotum, but fitting pretty closely to the abdomen ; uniform deep shining piceous. Tegmina of $q$ covering about two-thirds of the abdomen. Wings absent or fully developed, and extending beyond the tips of the cerci. Legs and abdomen fuscous, the former more or less variegated with pale testaceous, the hind femora without bands upon the inner surface. Ovipositor a little more than one-half as long as the hind femora, slightly arcuate, and feebly expanded at the base of the apical fourth, each blade bearing an irregular row of rather sharp teeth, the basal ones fine and close together, the apical coarse and unusually far apart.

Length of bady, of $8 \mathrm{~mm}$., क $8.5 \mathrm{~mm}$; pronotum, of $1.5 \mathrm{~mm}$., क I. $6 \mathrm{~mm}$., tegmen, of $5.4 \mathrm{~mm}$., क $3.4 \mathrm{~mm}$; hind femur, of $4.5 \mathrm{~mm}$., क $5 \mathrm{~mm}$. ; ovipositor, $3.3 \mathrm{~mm}$.

This species is most related to $N$. confusus and $N$. palustris, and also resembles $N$. exiguus in some respects. It differs from all three in 
the smaller head and narrower pronotum, the width of which, in angusticollis, is less than the dorsal field of the tegmina in their natural position. It differs from palustris in the much greater size, the longer and broader tegmina in the male, lighter maxillary palpi and shorter ovipositor, with more irregular teeth. From confusus the male of angusticollis differs in the longer and broader tegmina, those of confusus covering only threefourths of the abdomen, and in the uniform coloration of the hind femora, those of confusus being blotched and spotted on the inner surface. The females of angusticollis approach those of confusus so closely that they are separated with difficulty. The last two joints of the maxillary palpi in the latter are white, those of the former light brown; the hind femora and ovipositor are somewhat shorter in confusus, while the pronotum as mentioned before is broader than in angusticollis. From exiguus, angusticollis differs in the much darker and more uniform coloration, the much broader body and tegmina in the male, narrower hind femora, and in the somewhat longer and more sharply-toothed ovipositor.

Although neither has been reported from Ontario, I have figured both exiguus and confusus from specimens kindly loaned me by Mr. Blatchley, because it is thought that this will aid in the separation of these difficult species, and it is quite possible that both, especiaily exiguus, will eventually be found to occur in Ontario. Angusticollis is, next to fasciatus, the commonest Nemobius in Ontario. It frequents low grounds of almost any kind, but delights especially in low grassy borders "of swampy woods or clearings in swamps. I have found it in abundance in sphagnum moss when growing in such localities, but have not met with it in the open peatbogs where $N$. palustris occurs. It is also found beneath stones along the margins of lakes and streams.

I first discovered this insect through its stridulation, which I heard among the granite boulders which line the shores of Lake Simcoe at De Grassi Pt. It was a high-pitched continuous trill of considerable volume, and although I could approach the performer within a few feet, it was always necessary to disturb the rock in order to expose him. This, of course, not only silenced him, but allowed him to make himself scarce, and it was not until after repeated efforts that I at last secured one of the little musicians.

Of the long-winged form I have but a single pair, a male taken at De Grassi Pt., July 30, I90 I, and a female from the Severn River, Aug. 24, 1898. 
This species reaches maturity about the last week of July, and continues till November.

Localities: Toronto, Sept.-Nov.; Lake Simcoe, July 29-Sept. I 4 ; Sarnia, Aug. 15, I90 I ; Southampton, Aug. 20, I90 I ; Owen Sound, Aug. 31, 1901 ; Severn River, Aug. 24, I898.

(To be continued.)

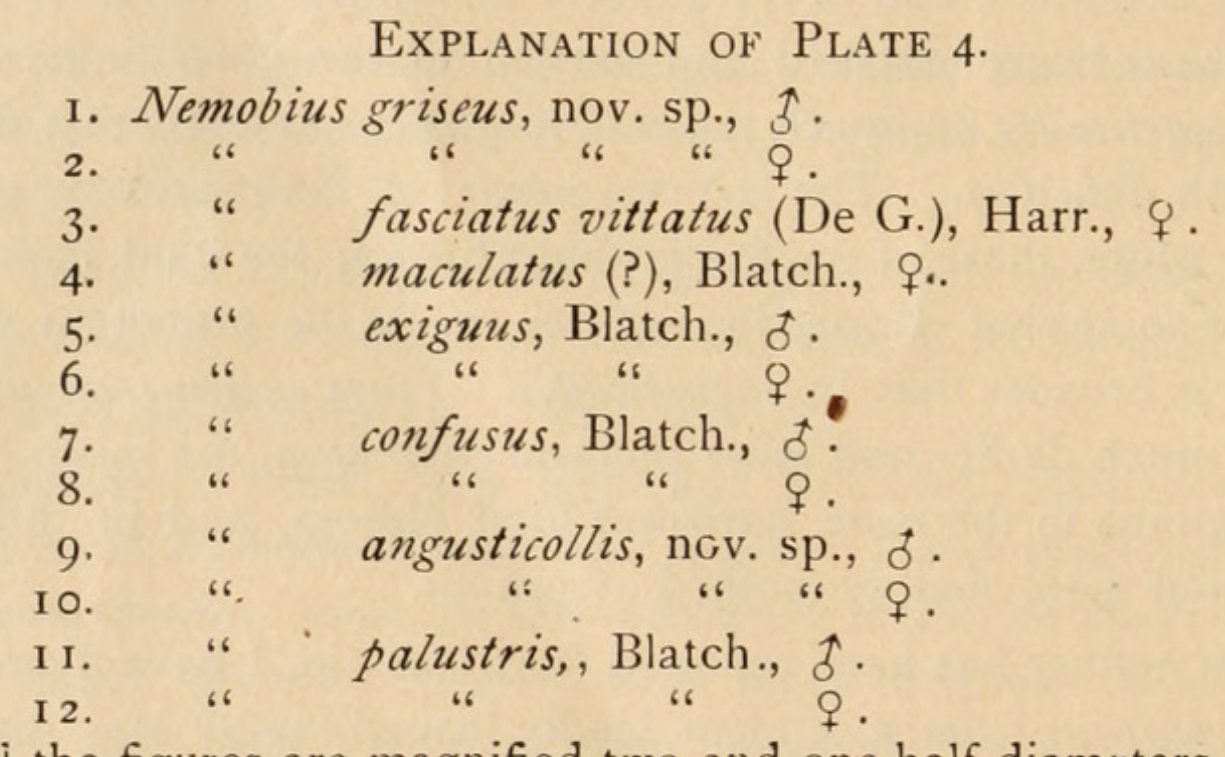

Ali the figures are magnified two and one half diameters.

THE REVEREND P. JEROME SCHMITT.

We regret to chronicle the death of the Rev. P. Jerome Schmitt at St.

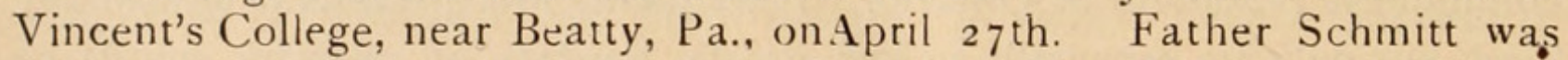
well known to the entomological world as a most careful and able worker, generous with his specimens and his time. He will be sadly missed by those who had the privilege of his acquaintance.

Father Schmitt was born at Neuhausen, Wurtemberg, May 30, 1857; he came to St. Vincent's College in 1869 , and in 1876 joined the Benedictine Order. In $\mathrm{I} 88 \mathrm{I}$ he was ordained priest of the Roman Catholic Church, and spent the greater part of the remaining years of his life in teaching the classics at the College. He found time for a great deal of close work with the Coleoptera, and was especially devoted to the study of some of the minute Clavicornia, as will be seen by reference to the writings of present-day authors. At the time of his seizure by the disease which resulted in his death, he was engaged on a descriptive catalogue of the Pselaphidæ collected in Brazil by H. H. Smith.

His collections and manuscripts remain at the College where his life was spent, and the material collected by him will no doubt be carefully preserved by his confreres. It has formed the basis of numerous records in Dr. Hamilton's Catalogue of the Coleoptera of Western Pennsylvania, and has furnished types of many new species described during the past ten years. - H. F. W. 


\section{$2 \mathrm{BHL}$ Biodiversity Heritage Library}

Walker, E. M. 1904. "The Crickets of Ontario." The Canadian entomologist 36, 181-188. https://doi.org/10.4039/Ent36181-7.

View This Item Online: https://www.biodiversitylibrary.org/item/22119

DOI: https://doi.org/10.4039/Ent36181-7

Permalink: https://www.biodiversitylibrary.org/partpdf/13632

\section{Holding Institution}

MBLWHOI Library

\section{Sponsored by}

MBLWHOI Library

\section{Copyright \& Reuse}

Copyright Status: NOT_IN_COPYRIGHT

This document was created from content at the Biodiversity Heritage Library, the world's largest open access digital library for biodiversity literature and archives. Visit BHL at https://www.biodiversitylibrary.org. 